\title{
Penyebab Rendahnya Hasil Belajar Peserta Didik Kelas X IIS Mata Pelajaran Sosiologi Semester Ganjil Tahun Ajaran 2020/2021 di SMAN 10 Padang
}

\author{
Atika Permata Bunda ${ }^{1}$, Junaidi Junaidi ${ }^{2}$, \\ 1,2 Universitas Negeri Padang \\ Email: atikapermatabunda99@gmail.com, junaidiunp@fis.ac.id
}

\begin{abstract}
Abstrak
Latar belakang dari penelitian ini adalah rendahnya hasil belajar peserta didik kelas X IIS mata pelajaran sosiologi pada tahun ajaran 2020/2021 di SMAN 10 Padang. Hal ini berbeda dengan hasil belajar sosiologi peserta didik di kelas XII dan XI IIS yang tinggi, padahal pembelajaran sosiologi dibelajarkan oleh satu guru yang sama untuk semua tingkatan kelas. Tujuan penelitian adalah untuk mengetahui penyebab rendahnya hasil belajar peserta didik di kelas X IIS mata pelajaran sosiologi di SMAN 10 Padang. Metode penelitian yang digunakan adalah pendekatan kualitatif, dengan tipe penelitian studi kasus, pemilihan informan dilakukan secara purposive sampling, pengumpulan data dilakukan melalui observasi, wawancara mendalam, dan studi dokumentasi. Data dianalisis dengan teknik analisis interaktif Miles dan Huberman yaitu dengan cara reduksi data, penyajian data dan menarik kesimpulan. Berdasarkan hasil penelitian yang peneliti lakukan selama berada di lapangan yaitu di SMAN 10 Padang, maka dapat ditarik kesimpulan bahwa penyebab rendahnya hasil belajar peserta didik kelas X IIS yaitu: (1) Tidak efektifnya pembelajaran selama daring, (2) Kebijakan Pemerintah dalam penerimaan peserta didik baru melalui sistem zonasi.
\end{abstract}

Kata kunci: Hasil Belajar, Pembelajaran Sosiologi

\begin{abstract}
The background of this study is the low learning outcomes of students of class XIIS sociology subjects in the 2020/2021 School Year at SMAN 10 Padang. Class XII IIS and XI IIS showed high student learning outcomes, but all classes X IIS student learning results are low, whereas all classes IIS School Year 2020/2021 at SMAN 10 Padang taught by one teacher of sociology the same. The purpose of the study was to find out the cause of the low learning outcomes of students of class X IIS sociology subjects at SMAN 10 Padang. To analyze a study entitled Causes of Low Learning Outcomes of Students of Class X IIS Sociology Subjects 2020/2021 at SMAN 10 Padang, researchers used the theory of diffusion of innovation in education according to Rogers. In the diffusion theory according to Rogers there are several models of innovation process oriented towards individuals namely: realizing, paying attention, assessing, trying and accepting. The research method used is qualitative approach, with case study type, informant selection is conducted by purposive sampling with 8 informants, observational data collection, in-depth interviews, and dokumtasi studies. The data is analyzed with Miles and Huberman's interactive analysis techniques by reducing data, presenting data and drawing conclusions. Based on the results of research conducted while in the field, namely at SMAN 10 Padang, it can be concluded that the causes of low learning outcomes of students of class X IIS are: (1) Ineffective learning during online, (2) Government Policy in the acceptance of new learners through the zoning system.
\end{abstract}

Keywords: Learning Outcomes, Low Causes, Learners

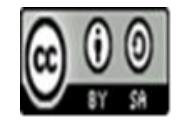

Received: May 5, 2021 $\quad$ Revised: June 6, 2021 Accepted: June 9, 2021




\section{Pendahuluan}

Pendidikan merupakan bagian dari pembangunan, proses pembangunan tidak bisa dipisahkan dari pendidikan. Pembangunan ditujukan dan diarahkan untuk mengembangkan manusia agar berkualitas. Manusia yang berkualitas dapat dilihat salah satunya dari segi pendidikan. Hal tersebut terkandung dalam tujuan Pendidikan Nasional menurut Undang-undang No. 20 Tahun 2003 pasal 3 (Sujana, 2019) adalah mengembangkan potensi peserta didik agar menjadi manusia yang beriman dan bertakwa kepada Tuhan Yang Maha Esa, berakhlak mulia, sehat, berilmu, cakap, kreatif, mandiri dan menjadi warga negara yang demokratis serta bertanggung jawab. Berdasarkan tujuan pendidikan nasional tersebut, sekolah sebagai lembaga pendidikan bertugas untuk mengembangkan potensi peserta didik agar mampu memiliki kemampuan sesuai yang dicita-citakan. Salah satunya adalah melalui pelaksanaan pembelajaran sosiologi. Tujuan pendidikan nasional berhasil tercapai dalam pembelajaran sosiologi jika peserta didik mampu menguasai materi pokok pembelajaran. Hal ini dapat terlihat dari hasil belajar peserta didik setelah mengikuti proses pembelajaran.

Hasil belajar menurut Nana Sudjana (Sudjana, 2011) adalah perubahan tingkah laku sebagai hasil belajar yang didalamnya mencakup bidang kognitif, afektif, dan psikomotorik. Kemudian menurut Asep Jihad (Jihad, 2009) hasil belajar adalah perubahan tingkah laku peserta didik secara nyata setelah dilakukan proses belajar mengajar yang sesuai dengan tujuan pembelajaran. Jadi dapat disimpulkan bahwa hasil belajar adalah suatu hasil yang dicapai setelah mengalami proses belajar dengan memperoleh ilmu pengetahuan yang mengubah tingkah laku peserta didik sesuai dengan tujuan pembelajaran. Peserta didik (Ramli, 2015) adalah anak yang belum memiliki kedewasaan dan memerlukan orang lain untuk mendidiknya sehingga menjadi individu yang dewasa, memiliki jiwa spiritual, aktifitas dan kreatifitas sendiri. Dengan demikian, peserta didik adalah individu yang memiliki potensi untuk berkembang dan berusaha mengembangkan potensinya melalui proses pendidikan.

Pada hasil observasi awal peneliti memperoleh data hasil ulangan harian sosiologi peserta didik pada KD 3.1 di kelas X IIS semester ganjil tahun ajaran 2020/2021 di SMAN 10 Padang, diperoleh fakta bahwa hasil belajar peserta didik masih rendah. Berikut data tersebut disajikan dalam bentuk tabel:

Tabel 1. Skor UH Sosiologi Kelas XII, XI, X Kelas IIS Pada KD 3.1

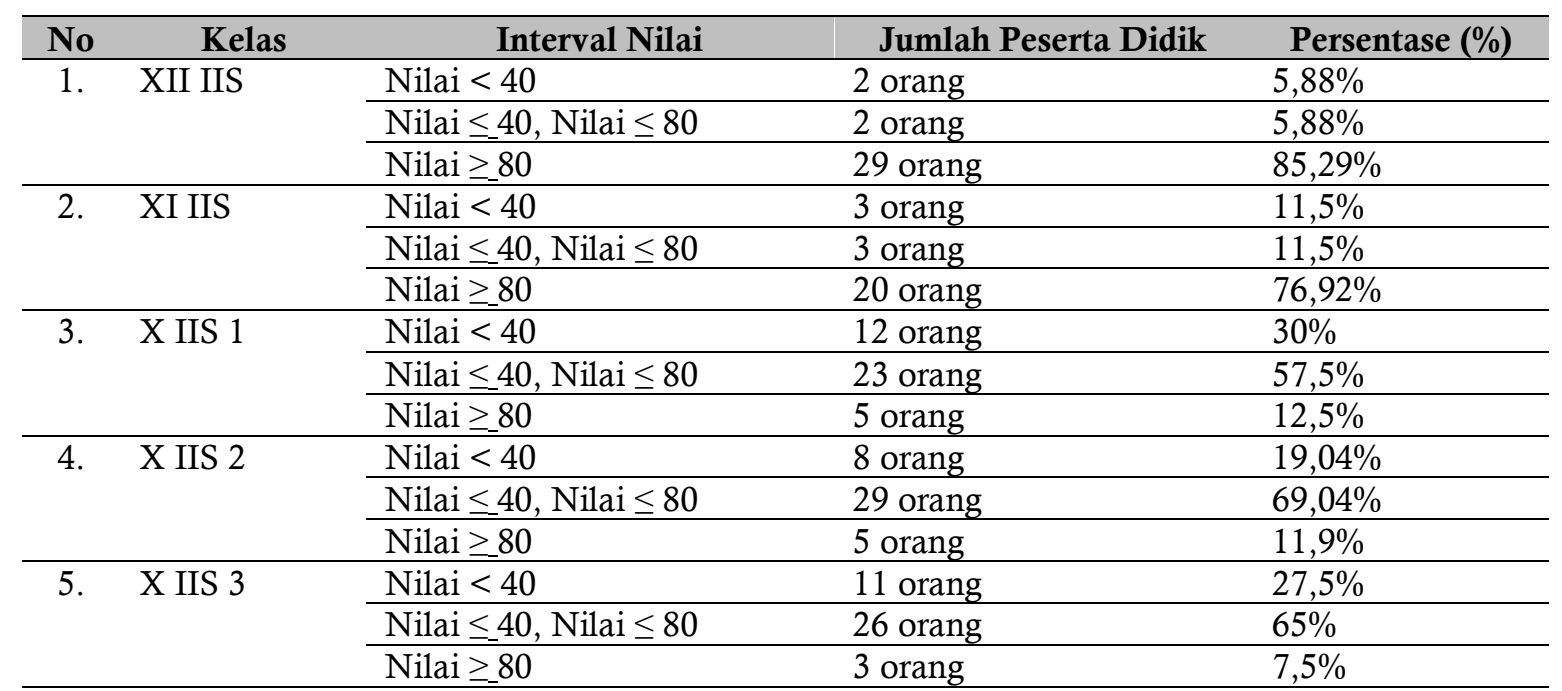

Sumber: Guru Mata Pelajaran Sosiologi Kelas IIS 
Berdasarkan data tabel di atas, berdasarkan skor UH KD 3.1 peserta didik pada kelas XII IIS terdapat $85,29 \%$ peserta didik yang mendapatkan skor di atas 80 , dan pada kelas XI ada $76,92 \%$ peserta didik yang skor UH nya berada si atas 80, sedangkan pada kelas X IIS 1 ada 12,5\% peserta didik, XI IIS 2 terdapat 11,9\% peserta didik dan 7,5\% peserta didik kelas X IIS 3 yang mendapatkan skor di atas 80. Berdasarkan data di atas dapat disimpulkan bahwa skor UH KD 3.1 peserta didik pada kelas XII IIS dan kelas XI IIS menunjukkan hasil belajar peserta didik tinggi, sedangkan semua kelas X IIS mehasil belajarnya masih rendah, padahal semua kelas-kelas IIS di SMAN 10 Padang diajarkan oleh satu guru sosiologi yang sama.

Beberapa penelitian yang telah dilakukan, yaitu penelitian yang telah dilakukan oleh Azmin Mane dan Surdin yang berjudul Faktor-faktor Penyebab Rendahnya Hasil Belajar Peserta Didik Pada Mata Pelajaran Geografi di SMA Negeri 1 Mawasangka. Hasil pembahasan menunjukkan bahwa dari 50 orang peserta didik yang rendah hasil belajarnya pada mata pelajaran geografi, sebanyak 41 orang disebabkan kurangnya ketersediaan buku cetak, sebanyak 28 peserta didik disebabkan kurangnya minat belajar peserta didik, sebanyak 14 peserta didik disebabkan kurangnya pendidikan orang tua, sebanyak 19 orang peserta didik disebabkan kurangnya penghasilan orang tua, sebanyak 10 peserta didik dipengaruhi oleh lingkungan sekolah, sebanyak 12 orang peserta didik dipengaruhi oleh suasana rumah dan sebanyak 3 orang peserta didik dipengaruhi cacat tubuh (Mane \& Surdin, 2016). Selanjutnya, penelitian yang dilakukan oleh Riah Reski Sirajuddin yang berjudul Faktor-faktor Penyebab Rendahnya Hasil Belajar Peserta Didik Siswa Kelas XI IPS pada Mata Pelajaran Sosiologi di SMAN 15 Makassar. Hasil pembahasan menunjukkan bahwa: Faktor-faktor penyebab rendahnya hasil belajar peserta didik kelas XI IPS pada mata pelajaran sosiologi di SMAN 15 Makassar dipengaruhi oleh beberapa faktor ialah faktor internal dan eksternal. Faktor internal meliputi; kemampuan belajar yang menurun, motivasi belajar yang kurang, sikap dan perasaan yang kurang menyenangkan dipengaruhi oleh faktor eskternal meliputi; keadaan sosial kultural peserta didik hingga mempengaruhi secara psikis (Sirajuddin, 2017). Kemudian, penelitian yang dilakukan oleh Trisna yang berjudul Faktor-faktor Dominan Penyebab Rendahnya Nilai Mid Semester Mata Pelajaran Sosiologi Peserta Didik Kelas XI IPS SMAN 2 Koto Baru Kabupaten Dharmasraya. Hasil pembahasan menunjukkan bahwa faktor dominan penyebab rendahnya nilai mid semester yaitu: faktor malas; faktor guru, peserta didik tidak mengerti guru menjelaskan pelajaran; faktor teman sebaya; pengatuh handphone; faktor psikis (Trisna, 2017). Artikel ini bertujuan untuk mengetahui penyebab rendahnya hasil belajar peserta didik kelas X IIS mata pelajaran sosiologi pada semester ganjil tahun ajaran 2020/2021 di SMAN 10 Padang.

\section{Metode Penelitian}

Pendekatan penelitian yang digunakan adalah pendekatan kualitatif. Pengertian pendekatan kualitatif menurut Sugiyono (Sugiyono, 2015) adalah penelitian yang lebih menekankan pada makna dari suatu masalah. Tipe penelitian yang digunakan adalah studi kasus. Studi kasus termasuk dalam penelitian analisis deskriptif, tipe penelitian studi kasus ini cocok dengan penelitian yang dilakukan oleh peneliti, karena peneliti akan mendeskripsikan penyebab rendahnya hasil belajar peserta didik kelas X IIS di SMAN 10 Padang secara mendalam.

Pemilihan informan digunakan teknik purposive sampling (sampel bertujuan). Menurut Sugiyono (Sugiyono, 2015) purposive sampling adalah menetapkan informan sebelum melakukan penelitian, dengan menetapkan kriteria tertentu yang harus dipenuhi oleh orang yang akan dijadikan sumber informasi. Adapun jumlah informan yang sesuai dengan kriteria yang peneliti pilih sebanyak 18 orang yang terdiri dari 1 guru sosiologi, 15 orang peserta didik, 1 kepala sekolah dan 1 orang tua peserta didik.

Teknik pengumpulan data yang digunakan dalam penelitian ini adalah, observasi, wawancara dan studi dokumentasi. Jenis observasi yang peneliti dipilih adalah observasi 
partisipasi pasif. Peneliti dalam observasi pasif ini mendatangi tempat yang diamati sewaktu pengumpulan data, namun tidak ikut dalam kegiatan sehari-hari informan. Pengamatan dilakukan mengenai aktivitas informan dan kondisi tempat penelitian yaitu kondisi kelas dan kondisi sekolah. Dalam penelitian ini, peneliti melakukan observasi proses pembelajaran sosiologi JuliDesember 2020 dan dilanjutkan pada semester Januari-Juni 2021 untuk proses pengumpulan data wawancara dan lainnya. Selanjutnya, teknik wawancara yang digunakan adalah wawancara mendalam. Wawancara mendalam dilakukan terhadap semua informan yang terlibat, sehingga memberikan informasi yang mendalam tentang permasalahan yang diteliti. Sebelum melakukan wawancara, peneliti menjalin hubungan dan komunikasi yang baik dengan informan agar tercipta suasana yang nyaman ketika wawancara berlangsung. Tak hanya itu, pertanyaan wawancara dirancang berdasarkan pedoman wawancara, ketika wawancara berlangsung peneliti juga mengajukan pertanyaan sehingga peneliti mendapatkan informasi mendalam. Hasil wawancara peneliti catat di buku catatan dan rekaman wawancara dengan handphone. Kemudian studi dokumentasi, menurut Suharsimi Arikunto (Arikunto, 2006) dokumentasi adalah mencari dan mengumpulkan data mengenai hal-hal yang berupa catatan, transkip, buku, surat kabar, majalah, notulen, rapor, agenda, dan sebagainya. Dokumentasi yang peneliti kumpulkan adalah hasil belajar dan daftar absensi peserta didik.

Pengujian keabsahan data dalam penelitian ini menggunakan teknik triangulasi. Triangulasi data dilakukan untuk menguji data dengan cara mengecek data atau informasi dari berbagai sumber. Triangulasi data dilakukan untuk memperkuat data yang diperoleh dari lapangan, maka penelitian ini menggunakan jenis triangulasi data yaitu: triangulasi sumber dan triangulasi metode (Sugiyono, 2015). Triangulasi sumber dilakukan dengan cara mengajukan beberapa pertanyaan yang sama kepada informan untuk mendapatkan data yang sama. Triangulasi metode dilakukan dengan membandingkan hasil observasi, wawancara dan dokumentasi, sehingga memperoleh data yang valid.

Teknik analisis data dalam penelitian ini menggunakan analisis Miles dan Huberman (Sugiyono, 2015) yaitu reduksi data, penyajian data, dan kesimpulan. Langkah-langkah dalam menganalisis data yaitu: peneliti merangkum hasil dari observasi, wawancara dan dokumentasi yang dianggap penting; setelah hasil penelitian dirangkum, peneliti melakukan analisis deskriptif yang dikaitkan dengan teori; setelah data terkumpul, dirangkum dan dianalisis deskriptif serta dikaitkan dengan teori, data disimpulkan. Data disimpulkan untuk memberikan makna terhadap data yang telah dianalisis.

\section{Hasil dan Pembahasan}

Hasil belajar menurut Nana Syaodih Sukmadinata (Sukmadinata, 2005) merupakan realisasi potensial atau kapasitas yang dimiliki seseorang. Penguasaan hasil belajar seseorang dalam dilihat dari perilakunya, baik perilaku dalam bentuk penguasaan pengetahuan, keterampilan berfikir maupun keterampilan motorik. Dengan demikian hasil belajar merupakan bagian terpenting dalam proses pembelajaran.

SMAN 10 Padang adalah salah satu SMA berprestasi yang berstatus negeri yang berlokasi di Jalan Situjuh, Kecamatan Padang Timur, Provinsi Sumatera Barat. Struktur kepemimpinana SMAN 10 Padang berjumlah 5 orang dan jumlah guru sebanyak 59 orang guru dengan berbagai mata pelajaran. Sekolah ini dilengakapi sarana dan prasarana yang cukup untuk mendukung proses pembelajaran peserta didik. SMAN 10 Padang hanya memiliki satu guru sosiologi. Semua kelas IIS yang berjumlah 5 kelas diampu oleh satu guru Ibu Y.

Berdasarkan penelitian yang telah dilakukan dapat diketahui penyebab rendahnya hasil belajar peserta didik kelas X IIS mata pelajaran sosiologi di SMAN 10 Padang ada dua yaitu (1) tidak efektifnya pembelajaran daring, (2) kebijakan pemerintah tentang penerimaan peserta didik melalui sistem zonasi.

Jurnal Sikola: Jurnal Kajian Pendidikan dan Pembelajaran Vol. 2, No. 4, Th. 2021 


\section{Tidak Efektifnya Pembelajaran Dalam Jaringan (daring)}

Pembelajaran secara daring dianggap menjadi solusi kegiatan belajar mengajar tetap jalan di tengah pandemi covid-19. Namun pada kenyataannya, pembelajaran daring tidak efektif untuk dilakukan. Hal ini senada yang dikemukan oleh Y selaku guru sosiologi di SMAN 10 Padang menyatakan:

"Selama pembelajaran daring, materi yang disampaikan belum tentu dipahami oleh semua peserta didik. Saya tidak bisa mengetahui peserta didik yang paham dan yang tidak paham. Dikarenakan peserta didik hanya mengiyakan jika saya mengirimkan materi di google classroom. Kemudian, keterbatasan jam mengajar di saat pembelajaran daring, sehingga diskusi tidak terlaksana dengan baik. Apalagi peserta didik kelas X IIS baru memasuki jenjang Sekolah Menengah Atas (SMA), jadi sesuatu hal yang baru untuk pembelajaran daring. Pembelajaran daring tentu menggunakan jaringan internet dan handphone, tidak semua peserta didik yang mempunyai handphone dan jaringen internet yang memadai". (Wawancara tanggal 29 Maret 2021).

Berdasarkan informasi yang didapatkan dari ibu Y, dapat dikatakan bahwa kendala yang ditemui saat pembelajaran daring, yaitu: (1) guru tidak mengetahui peserta didik paham atau tidak dengan materi; (2) keterbatasan jam mengajar di saat pembelajaran daring, dan tidak semua peserta didik yang memiliki handphone dan jaringan yang memadai.

Kendala pertama yang ditemui saat pembelajaran daring yaitu guru tidak mengetahui peserta didik paham atau tidak dengan materi,guru tidak mengetahui respon peserta didik setelah menrima materi dari guru melalui google classroom. Peserta didik cenderung menjawab mengerti terhadap materi yang telah dikirimkan. Hal ini senada yang dikemukakan oleh BA kelas X IIS3 yang menyatakan:

"Jika bu Y menyampaikan materi di google classroom dan menanyakan materi apakah paham atau tidak, saya bilang saja sudah paham walaupun kadang saya belum baca materinya, agar pembelajaran cepat selesai" (wawancara tanggal 12 April 2021).

Berdasarkan informasi yang peneliti dapatkan dari BA, dapat dipahami bahwa guru tidak mengetahui peserta didik paham atau tidak dengan materi karena peserta didik menjawab sudah paham agar pembelajaran cepat selesai, padahal sebenarnya belum. Hal tersebut terjadi karena peserta didik merasa bosan dan kurang tertarik dengan pembelajaran daring di google classroom. Hal senada dikemukakan oleh FN kelas X IIS 1 yang menyatakan:

"Saya merasa bosan saat pembelajaran daring, sumber buku hanya menggunakan buku LKPD dan buku cetak. Kadang guru mengirimkan materi dengan video, gambar dan artikel lalu di unggah di google classroom. Setelah pembelajaran berakhir, guru memberikan tugas yang di ada di LKPD, di tambah tugas dari mata pelajaran yang lain" (wawancara tanggal 12 April 2021).

Berdasarkan informasi yang peneliti dapatkan dari FN kelas X IIS 1, dapat dipahami bahwa peserta didik merasa bosan dengan metode pembelajaran yang digunakan guru tidak disukai oleh peserta didik, media pembelajaran yang kurang mendukung dalam proses pembelajaran, terlalu banyak hafalan, tugas-tugas dan tekanan dari mata pelajaran dari guru lainnya.

Kendala kedua yang ditemui saat pembelajaran daring yaitu keterbatasan jam mengajar di saat pembelajaran daring, sehingga diskusi tidak terlaksana dengan baik. Hal ini senada yang dikemukakan oleh Y selaku guru sosiologi di SMAN 10 Padang menyatakan:

"Jam mengajar saat pembelajaran daring 30 menit untuk 1 jam pelajaran. Yang awalnya 45 menit untuk 1 jam pelajaran. Dalam waktu singkat tersebut tidak cukup waktu untuk melakukan diskusi. Kalau masih banyak waktu tersisa baru saya melakukan diskusi dengan 
peserta didik di whatsapp, jika jam mengajar sudah habis, saya memberikan tugas di LKPD atau tugas lain" (wawancara tanggal 29 Maret 2021).

Berdasarkan informasi yang didapatkan dari ibu Y, dapat dikatakan bahwa perubahan jam mengajar yang awalnya 45 menit untuk 1 jam, saat pembelajaran daring berkurang menjadi 30 menit untuk 1 jam. Keterbatasan jam mengajar ini mengakibatkan diskusi jarang dilakukan.

Selanjutnya kendala ketiga yang ditemui saat pembelajaran daring yaitu tidak semua peserta didik memiliki handphone dan jaringan internet yang memadai. Hal ini senada yang dikemukakan oleh Bapak D selaku kepala sekolah SMAN 10 Padang yang menyatakan:

"Syarat pembelajaran daring tentu memerlukan handphone dan jaringan internet yang memadai. Setelah pelaksanaan pembelajaran daring dilakukan, ternyata ada beberapa peserta didik yang belum memiliki handphone. Ada beberapa peserta didik yang belum pernah mengikuti proses pembelajaran daring karena tidak memiliki handphone, salah satunya peserta didik yang bernama SRP kelas X IIS1 yang tidak memiliki handhphone. Kemudian, jaringan internet yang kadang bermasalah yang menghambat proses pembelajaran daring. Karena hal tersebut, peserta didik tidak mengikuti proses pembelajaran.

Berdasarkan informasi yang peneliti dapatkan dari Bapak D, dapat dipahami bahwa ada beberapa peserta didik yang tidak memiliki handphone dan jaringan yang tidak memadai, sehingga mereka tidak mengikuti proses belajar mengajar. Hal senada dikemukakan oleh SRP kelas X IIS 1 dan BA kelas X IIS 3. SRP kelas X IIS1 yang menyatakan:

Pernyataan SRP kelas X IIS 1:

"Di rumah hanya memiliki satu handphone, sementara saya beradik kakak berlima, yang sekolah tiga orang. saya mendahulukan adik untuk sekolah, makanya saya jarang mengikuti pembelajaran daring. Kalau untuk membeli handphone baru rasanya tidak memungkinkan, dilihat kondisi ekonomi orang tua Ryan di saat pandemi sekarang" (Wawancara tanggal 12 April 2021)".

Pernyataan BA kelas X IIS 3 juga menyatakan:

"Saat pembelajaran daring kadang jaringan internet bermasalah. Misalnya guru mengirimkan materi berbentuk video atau power point, kalau jaringan bermasalah tidak bias di tonton dan lama untuk mendownload. Kemudian, pernah saat melakukan kuis di aplikasi quizizz jaringan internet bermasalah. Karena itu saya tidak mengikuti kuis dan nilai kuis Bunga kosong" (Wawancara tanggal 12 April 2021).

Berdasarkan informasi yang peneliti dapatkan dari peserta didik, dapat dipahami bahwa SRP tidak memilki handphone karena keterbatasan ekonomi, sehingga tidak bisa mengikuti pembelajaran daring. sementara BA kadang tidak mengikuti proses pembelajaran daring karena jaringan internet yang bermasalah.

Berdasarkan hasil wawancara, observasi dan dokumentasi yang peneliti temukan, dapat bahwa tidak efektinya pembelajaran daring menyebabkan rendahnya hasil belajar peserta didik. $\mathrm{Hal}$ ini terbukti dengan banyak kendala yang ditemukan saat pembelajaran daring dan berdampak pada hasil belajar peserta didik. Kendala tersebut yaitu: (1) guru tidak mengetahui peserta didik paham atau tidak dengan materi; (2) keterbatasan jam mengajar di saat pembelajaran daring; dan tidak semua peserta didik yang memiliki handphone dan jaringan yang memadai; (3) peserta didik merasa bosan saat pembelajaran daring; (4) kurang aktifnya peserta didik dalam pembelajaran daring; dan (5) peserta didik kurang tertarik saat pembelajaran daring.

Berdasarkan hasil wawancara, observasi dan dokumentasi yang peneliti temukan, dikuatkan dengan beberapa penelitian tentang tidak efektifnya pembelajaran daring. Menurut penelitian

Jurnal Sikola: Jurnal Kajian Pendidikan dan Pembelajaran Vol. 2, No. 4, Th. 2021 
yang dilakukan oleh Pipip Zulfa Huzaimah dan Risma Amelia dengan judul Hambatan yang Dialami Peserta Didik Dalam Pembelajaran Daring Matematika Pada Masa Pandemi Covid-19. Hasil pembahasan menunjukkan bahwa tidak efektifnya pembelajaran daring disebabkan yaitu: karena peserta didik kurang aktif; sarana dan prasarana yang kurang memadai, media pembelajaran yang tidak menarik; peserta didik dibebani oleh banyaknya tugas yang diberikan oleh guru yang membuat peserta didik stres (Huzaimah \& Amelia, 2021).

Selanjutnya, menurut penelitian yang dilakukan oleh Siti Nita Sari dan Haryono yang berjudul Dampak Pembelajaran Online Pada Mata Pelajaran Sosiologi di Masa Pandemi Covid19 di SMAN 4 Pandeglang. Hasil pembahasan menunjukkan proses pembelajaran daring yang terjadi di SMAN Pandeglang masih kurang kondusif dikarenakan ada beberapa faktor yang mempengaruhi proses pembelajaran seperti faktor internal dan faktor eksternal. Peserta didik mengalami penurunan minat, motivasi belajar di kelas. Metode pembelajaran yang digunakan oleh guru berbeda dari biasanya tatap muka yang berinteraksi langsung dengan peserta didik sedangkan jika daring guru menggunakan metode lain berupa penerapan aplikasi-aplikasi yang mendukung dalam kegiatan belajar mengajar seperti whatsapp, google meet dan lainnya (Sari \& Haryono, 2021).

Kemudian, menurut penelitian yang dilakukan oleh Aas Aliana Futriani Hidayah dan kawan-kawan yang berjudul Efektifitas Pembelajaran Daring di Masa Pandemi Covid-19. Hasil Pembahasan menunjukkan, bahwa penggunaan media daring atau platform belajar dinilai bisa menjadi solusi agar peserta didik tetap bisa mengikuti proses belajar-mengajar di jenjang manapun, baik PAUD, sekolah dasar, sekolah menengah pertama, sekolah menengah atas, dan perguruan tinggi. Akan tetapi, cara ini dalam pelaksanaannya mengalami banyak kendala terkait dengan efektivitas proses belajar mengajarnya. Kendala tersebut yaitu: keluhan pemberian tugas dan kesulitan memahami materi pelajaran; gangguan jaringan internet; merasa jenuh; keterbatasan penguasaan teknologi dan tersedianya kuota internet.

Berdasarkan dari ketiga penelitian di atas, dapat dipahami bahwa pelaksanaan pembelajaran daring memiliki beberapa kendala, sehingga pembelajaran mengalami tidak efektif proses belajar mengajaranya. Karena hal tersebut menyebabkan hasil belajar peserta didik rendah.

\section{Kebijakan Pemerintah tentang Penerimaan Peserta Didik Melalui Sistem Zonasi}

Penyebab rendahnya hasil belajar peserta didik kelas X IIS mata pelajaran sosiologi di SMAN 10 Padang adalah kebijakan pemerintah tentang penerimaan peserta didik melalui sistem zonasi. SMAN 10 Padang disebut salah satu sekolah berprestasi karena menghasilkan banyak peserta didik yang mengukir prestasi dengan menjuarai berbagai kompetisi setiap tahunnya. Namun sejak Kementerian Pendidikan dan Kebudayaan (Kemendikbud) menerbitkan Peraturan Menteri Pendidikan (Permendikbud) No. 51 tahun 2018 yang menyatakan bahwa sekolah yang diselenggarakan oleh pemerintah daerah wajib menerima calon peserta didik yang berdomisili pada radius zona terdekat dari sekolah paling sedikit sebesar $90 \%$ dari total jumlah keseluruhan peserta didik yang diterima di Sekolah Menengah Atas. Banyak dampak yang timbul akibat dari implementasi sistem zonasi tersebut yaitu: pertama dampak bagi guru; kedua imbas terhadap sekolah; dan yang ketiga imbas bagi masyarakat.

Implementasi sistem zonasi ini juga berimbas bagi standar kualitas peserta didik yang diterima di sekolah. Banyak guru yang mengeluh peserta didik memiliki keberagaman kemampuan akademik sehingga berdampak pada perolehan hasil belajar peserta didik yang banyak di bawah KKM. Hal ini senada yang dikemukakan oleh Y selaku guru sosiologi di SMAN 10 Padang menyatakan:

"Peserta didik diterima sebelum zonasi yaitu kelas XI dan XII sekarang, sedangkan peserta didik diterima karena zonasi yaitu kelas X. Perbedaan hasil belajar peserta didik yaitu peserta didik kelas X IIS banyak memperoleh nilai di bawah KKM. Kemudian, 
keberagaman kemampuan akademik peserta didik yang berbeda dengan peserta didik tahun-tahun sebelum sistem zonasi. (Wawancara tanggal 29 Maret 2021).

Berdasarkan informasi yang didapatkan dari ibu Y, dapat dikatakan bahwa dampak sistem zonasi yaitu: perbedaan hasil belajar peserta didik kelas XI IIS dengan kelas X IIS; peserta didik kelas X IIS memiliki keberagaman kemampuan akademik yang berbeda-beda.

Pertama, dampak sistem zonasi adalah perbedaan hasil belajar peserta didik kelas XI IIS dengan kelas X IIS. Hal ini senada yang dikemukakan oleh Bapak D selaku kepala sekolah di SMAN 10 padang yang menyatakan:

"Dari sistem zonasi ini tentu adanya perbedaan hasil belajar peserta didik yang diterima sebelum sistem zonasi dengan setelah dilaksanakan sistem zonasi. Biasanya yang masuk dan diterima ke SMAN 10 Padang adalah peserta didik yang memiliki nilai akademik yang tinggi, tapi sekarang peserta didik yang memiliki nilai biasa diterima di SMAN 10 Padang. Dari sistem zonasi tersebut terlihat perbedaan hasil belajar peserta didik. Peserta didik diterima sebelum zonasi yaitu kelas XI dan XII sekarang, sedangkan peserta didik diterima karena zonasi yaitu kelas X" (wawancara tanggal 19 April 2021).

Berdasarkan wawancara dengan Bapak D, dapat dipahami bahwa sebelum sistem zonasi peserta didik yang diterima di SMAN 10 Padang adalah peserta didik yang memiliki kemampuan akademik bagus yaitu kelas XII IIS dan kelas XI IIS, tetapi saat sistem zonasi dilaksanakan peserta didik yang memiliki nilai biasa dapat diterima dengan syarat jarak tempuh rumahnya dengan sekolah berada pada ketentuan system zonasi (dekat). Dampak dari sistem zonasi tersebut, menyebabkan perbedaan hasil belajar peserta didik kelas XI IIS dengan peserta didik kelas X IIS. Hal ini dapat dilihat dari tabel di bawah ini:

Tabel 2. Perbedaan Hasil Ulangan Harian dan Nilai Tugas pada KD 3.1 Semester Ganjil $2020 / 2021$

\begin{tabular}{cccc}
\hline No & Kelas & Rata-rata Nilai UH & Rata-rata Nilai Tugas \\
\hline 1 & XI IIS & 85,53 & 88,02 \\
\hline 2 & XI IIS & 86,63 & 88,56 \\
\hline 3 & X IIS 1 & 67,06 & 81,66 \\
\hline 4 & X IIS 2 & 60,04 & 82,52 \\
\hline 5 & X IIS 3 & 68,35 & 81,4 \\
\hline
\end{tabular}

Sumber: Guru Sosiologi SMAN 10 Padang

Berdasarkan hasil wawancara dan tabel, dapat dikatakan bahwa sistem zonasi menyebabkan perbedaan hasil belajar peserta didik kelas XI IIS dengan peserta didik kelas X IIS.

Kedua, dampak dari sistem zonasi adalah peserta didik kelas X IIS memiliki keberagaman kemampuan akademik. Hal ini senada yang dikemukakan oleh Bapak selaku kepala sekolah di SMAN 10 Padang yang menyatakan:

"Biasanya yang diterima di SMAN 10 Padang adalah peserta didik yang memiliki nilai akademik yang bagus dan berprestasi. Namun sejak tahun 2020, penerimaan peserta didik melalui sistem zonasi. Sistem zonasi dapat menyebabkan peserta didik yang berprestasi tidak dapat memilih sekolah berprestasi dikarenakan jarak tempuh rumah mereka yang jauh dari sekolah yang diinginkan. Namun sebaliknya peserta didik yang memiliki nilai biasa saja akan dapat memasuki SMAN 10 Padang dengan mudah karena jarak rumah mereka yang dengan sekolah dekat. Karena hal tersebut, peserta didik kelas X IIS di SMAN 10 Padang memiliki peserta didik dengan keberagaman kemampuan akademiknya. Ada

Jurnal Sikola: Jurnal Kajian Pendidikan dan Pembelajaran Vol. 2, No. 4, Th. 2021 
sebagian peserta didik kelas X IIS yang memiliki kemampuan akademik yang bagus, memiliki minat dan aktif dalam pembelajaran, sementara ada sebagian peserta didik kelas $\mathrm{X}$ IIS yang memilki kemampuan akademik yang biasa, membolos, terlambat, sulit untuk dibimbing, dan tidak aktif dalam pembelajaran" (wawancara tanggal 19 April 2021).

Berdasarkan hasil wawancara dengan Bapak $\mathrm{D}$, dapat dipahami bahwa dampak dari sistem zonasi adalah peserta didik kelas X IIS memilki keberagaman kemampuan akademiknya. Ada sebagian peserta didik yang memilki kemampuan akademik yang bagus dan ada sebagian yang memiliki kemampuan yang biasa.

Implementasi sistem zonasi berimbas bagi kualitas peserta didik yang diterima oleh sekolah. Dampak negatif yang ditimbukan dari adanya system penerimaan peserta didik melalui sistem zonasi ini adalah jumlah penerimaan peserta didik melalui jalur wilayah mengalami kenaikan dari awalnya $20 \%$ menjadi $90 \%$. Berdasarkan persentase penerimaan peserta didik yang lebih terfokus pada dekatnya jarak rumah dan sekolah menyebabkan sekolah unggul jarang mendapatkan peserta didik yang berasal dari siswa SMP/MTs yang berprestasi. Hal inilah yang menyebabkan banyak peserta didik yang memperoleh nilai dibawah kriteria ketuntasan minimal (KKM). Hal ini senada yang dikemukakan oleh Bapak D selaku kepala sekolah di SMAN 10 Padang yang menyatakan:

"Sebelum sistem zonasi dilaksanakan, penerimaan peserta didik lebih diutamakan peserta didik yang memiliki kemampuan akademik yang bagus. Saat sistem zonasi dilaksanakan, sekolah wajib menerima kuota 90\% peserta didik yang berdomisili dekat dengan sekolah dengan melampirkan Kartu Keluarga". (Wawancara tanggal 29 maret 2021).

Berdasarkan hasil wawancara dengan Bapak D dapat dipahami bahwa jumlah penerimaan peserta didik melaui jalur wilayah mengalami kenaikan menyebabkan banyak peserta didik yang memperoleh nilai dibawah kriteria ketuntasan minimal (KKM).

Berdasarkan hasil penelitian yang peneliti temukan, dikuatkan dengan beberapa penelitian tentang penerimaan peserta didik melalui sistem zonasi. Menurut penelitian yang dilakukan oleh Riski Tri Widyastuti yang berjudul Dampak Pemberlakuan Sistem Zonasi Terhadap Mutu Sekolah dan Peserta didik (Widyastuti, 2020). Hasil penelitian menunjukkan yakni: bagi calon peserta didik yang memiliki nilai akademiknya bagus tetapi jarak rumah antara sekolah jauh, maka peluang kecil untuk diterima, sehingga peserta didik akan mencari sekolah yang kurang kualitas sekolahnya, hal ini menjadi masalah karean pemerintah belum mampu menyetarakan kualitas setiap sekolah; dengan adanya sistem zonasi ini mengakibatkan guru bekerja estra untuk beradaptasi dengan peserta didik yang memiliki kemampuan yang berbeda-beda, hal ini terutama bagi guru yang mengajar di sekolah berprestasi; dampak dari zonasi ini berdampak bagi motivasi belajar peserta didik. Menurunya motivasi peserta didik disebabkan karena ia tahu bahwa bagus atau tidaknya nilainya ia akan tetap di terima di sekolah yang ada di lokasi domisilinya.

Selanjutnya, menurut penelitian yang dilakukan oleh Dany Miftahul Ula dan Irvan Lestari (Ula \& Lestari, 2020). Hasil pembahasan menujukkan bahwa kebijakan sistem zonasi berdampak bagi sekolah dan bagi masyarakat. Dampak tersebut yaitu: peserta didik banyak memperoleh nilai di bawah KKM; semakin banyak pelanggaran tata tertib; peserta didik sulit untuk dibimbing, memunculkan pelanggaran-pelanggaran baru yang belum pernah dilakukan oleh tahun sebelumnya; semangat saing dan semangat juang peserta didik rendah; kurang memiliki sopan santun terhadap guru; dan guru kesulitan untuk mengondisikan kelas.

Berdasarkan hasil penelitian yang telah dilakukan, dapat disimpulkan bahwa kebijakan sistem zonasi berdampak bagi guru, peserta didik, sekolah, dan bagi masyarakat. Bagi guru, guru kewalahan dengan kemampuan peserta didik yang berbeda-beda. Bagi peserta didik, peserta didik kurang bersemangat dan menurunnya motivasi belajar, sehingga menyebabkan rendahnya hasil belajar peserta didik kelas X IIS. Bagi sekolah, penerimaan peserta didik melaui jalur wilayah mengalami kenaikan menyebabkan banyak peserta didik yang memperoleh nilai dibawah kriteria

Jurnal Sikola: Jurnal Kajian Pendidikan dan Pembelajaran Vol. 2, No. 4, Th. 2021 
ketuntasan minimal (KKM). Dapat disimpulkan penyebab rendahnya hasil belajar peserta didik kelas X IIS di SMAN 10 Padang merupakan kombinasi antara faktor internal dan eksternal (N. M. Sari, Erianjoni, \& Sylvia, 2019), yaitu faktor internal yaitu faktor yang berasal dari dalam diri seseorang misalnya kemampuan, pengetahuan atau usaha, peserta didik sedangkan faktor eksternla yaitu faktor-faktor yang berasal dari luar misalnya faktor pembelajaran daring, keberuntungan masuk sekolah unggul karena sistem zonasi, kesempatan dan lingkungan.

\section{Kesimpulan}

Berdasarkan hasil penelitian yang peneliti lakukan terhadap penyebab rendahnya hasil belajar peserta didik pada pembelajaran sosiologi di kelas X IIS SMAN 10 Padang, diperoleh kesimpulan (1) Tidak efektinya pembelajaran daring; (2) kebijakan pemerintah tentang penerimaan peserta didik melalui sistem zonasi.

\section{Daftar Pustaka}

Arikunto, S. (2006). Metode Penelitian Kualitatif. Jakarta: Bumi Aksara.

Huzaimah, P. Z., \& Risma, A. (2021). Hambatan yang Dialami Siswa Dalam Pembelajaran Daring Matematika Pada Masa Pandemi COVID-19. Jurnal Cendekia: Jurnal Pendidikan Matematika, 5(1), 533-541.

Jihad, A. (2009). Evaluasi Pembelajaran. Yogyakarta: Multi Pressindo.

Mane, A., \& Surdin. (2016). Faktor Penyebab Rendahnya Hasil Belajar Siswa pada Mata Pelajaran Geografi di SMA Negeri 1 Mawasangka. Jurnal Penelitian Pendidikan Geografi, 41(2), 419-428.

Ramli, M. (2015). Hakikat Pendidik dan Hakikat Peserta Didik. Jurnal Ilmiah Pendidikan Agama Islam, 5(1), 1.

Sari, N. M., Erianjoni, E., \& Sylvia, I. (2019). Perilaku Siswa Menghadapi Ujian Nasional Berbasis Komputer di SMAN 3 Kota Pariaman Tahun 2018. Jurnal Perspektif, 2(1), 1-11. https://doi.org/10.24036/perspektif.v2i1.58

Sari, S. N., \& Haryono, H. (2021). Dampak Pembelajaran Online Pada Mata Pelajaran Sosiologi di Masa Pandemi Covid-19 di SMA 4 Pandeglang. Urnal Pendidikan Sosiologi Dan Humaniora, 12(1), 51-58.

Sirajuddin, R. R. (2017). Faktor-Faktor Penyebab Rendahnya Hasil Belajar Siswa Kelas XI IPS Pada Mata Pelajaran Sosiologi di SMAN 15 Makassar. Sosialisasi Pendidikan Sosiologi-FIS UNM, 4(1), 87-92.

Sudjana, N. (2011). Penilaian Hasil Proses Belajar Mengajar. Bandung: PT. Remaja Rosdakarya.

Sugiyono, S. (2015). Metode Penelitian Pendidikan. Bandung: Alfabeta.

Sugiyono, S. (2017). Metode Penelitian Kuantitatif, Kualitatif, dan R\&D. Jakarta: Alfabeta.

Sujana, I. (2019). Fungsi dan Tujuan Pendidikan Indonesia. Adi Widya: Jurnal Pendidikan Dasar, 4(1), 29. https://doi.org/10.25078/aw.v4i1.927

Sukmadinata, N. S. (2005). Landasan Psikologi Proses Pendidikan. PT Remaja Rosdakarya.

Trisna, T. (2017). Faktor-faktor Dominan Penyebab Rendahnya Nilai Mid Semester Mata Pelajaran Sosiologi Siswa Kelas XI IPS SMAN 2 Koto Baru Kabupaten Dharmasraya. Journal of Chemical Information and Modeling, 53(9), 1689-1699.

Ula, D. M., \& Lestari, I. (2020). Dampak Sistem Zonasi bagi Sekolah Menengah Pertama 1. Briliant: Jurnal Riset Dan Konseptual, 5(1), 10-18.

Widyastuti, R. T., Kristen, U., \& Wacana, S. (2020). Dampak Pemberlakuan Sistem Zonasi Terhadap Mutu Sekolah dan Peserta Didik. Edusaintek: Jurnal Pendidikan Sains Dan Teknologi, 7(1), 11-19. 